\author{
Gyu-Chang Yu, Woo-Sung Park, Yung-Ho Cho*
}

\title{
MNCs' HRM Strategy and Country of Origin Effect: Do North American, European and Japanese Firms Really Differ?**
}

Based upon the sample of 419 MNCs' subsidiaries in Korea, we examined the country of origin effect in the choice of MNCs' HRM strategy: transplantation, localization, and mixed. A multinominal logit regression analysis showed that there is an important country of origin effect in the choice between a localization strategy and a mixed strategy. North American MNCS tended to implement mixed strategy, while Japanese MNCs tended to adopt localization strategy. European MNCs were in the middle. The estimated log odds of choosing a localization strategy over a mixed strategy by Japanese subsidiaries were 1.79 times higher than European subsidiaries and 2.85 times higher than N. American subsidiaries; those by European subsidiaries were 1.59 times higher than N. American subsidiaries. However, the country of origin was not significantly related to the choice between a transplantation strategy and other strategies. We also examined two alternative factors influencing the HRM strategy of foreign subsidiaries: investment strategy and entry strategy. The implications of this and directions for future research are discussed.

Key words: Country of Origin, HRM Strategy, Localization, MNCs, South Korea

* Gyu-Chang Yu, Hanyang University, Woo-Sung Park, Kyunghee University, Yung-Ho Cho, Ajou University.

Corresponding Author: Gyu-Chang Yu, Ph.d., Associate Professor, School of Business, Hanyang University, 17 Haengdang-dong, Seongdong-gu, Seoul 133-792, Korea, e-mail: hr@hanyang.ac.kr

** Article received: March 12, 2007

Revised version accepted after double blind review: October 22, 2007. 


\section{Introduction}

With rapid globalization, international human resource management (IHRM) has become an increasingly important research field. During the 1990s, cross-border mergers and acquisitions became very active worldwide and the FDI by multinational companies (MNCs) tripled reaching U.S. $\$ 4,759$ billion (UN 2000). It has become an important and difficult task for MNCs to manage their foreign subsidiaries while considering global efficiency and local context at the same time.

The MNCs' behavior can be influenced both by socio-political situations (or external factors) and by the headquarter strategies and policies of the home country (or internal factors). For example, Holtbrugge and Berg (2004) found that the operations of German MNCs are influenced by several socio-political interest groups of their host countries. Also, there have been many research efforts to examine the behavior of MNCs, in particular the country of origin effect. This paper focuses on the HQ strategies of MNCs, controlling for socio-political factors by analyzing the human resource management (HRM) strategies of MNCs in Korea.

The country of origin effect has begun to receive renewed attention by several researchers and has given birth to an interesting debate between home country vs. host country effect (Rosenweig/Nohria 1994; Innes/Morris 1995; Roche/Geary 1996; Guest/Hoque 1996; Turner et al. 1997; Ferner 1997; Liu 2004; Glover/Wilkinson 2007). A central issue is whether the HRM of foreign subsidiaries is determined by the "foreignness" of the invested capital (country of origin) or by locally prevalent customs and practices (Roche/Geary 1996). In particular, whether there are significant differences between North American, European and Japanese subsidiaries has been a center of debate and empirical testing (Ferner 1997).

It seems that numerous bodies of research support the country of origin as an important factor explaining the MNCs' behavior. For example, many studies show American MNCs adopt a more centralized and formal management style in their foreign subsidiaries, and this management pattern exerts significant influence on local pay systems, collective bargaining, fringe benefits and training (Bartlett/Ghoshal 1989; Bomers/Peterson, 1977, Hamil 1984; Yeun/Hui 1993). More recent studies support the fact that HRM practices are considerably different according to the countries of origin (Kopp 1994; Rosenweig/Nohria 1994; Innes/Morris 1995; Roche/Geary 1996; Guest/Hoque 1996; Geary/Roche 2001).

In spite of this empirical evidence, however, the controversy over the country of origin effect has continued until now. Under a globalized economy, it can be argued that MNCs become stateless players detaching themselves from a specific nation. In this respect, the differences resulting from the country of origin could disappear or be diminished. For example, Turner et al. (1997a) comparing the HRM practices between US subsidiaries and Irish firms, find little evidence for the country of origin effect. Turner et al. (1997b) also show that there are no significant differences in the HRM practices between US and European subsidiaries. They claim that the HRM practices of MNCs in Ireland bear a close resemblance to those of indigenous firms. Their results imply that the MNCs' HRM practices become more isomorphic blurring the dif- 
ferences between foreign subsidiaries and indigenous firms, and between different countries of origin, due to the common use of the best practices and bench marking.

Recently, the country of origin effect has been also challenged by reverse diffusion. According to Edwards (1998), MNCs tend to import or diffuse innovative practices that turn out to be efficient in a specific subsidiary to headquarters or other foreign operations. Ferner and Varul (2000) show this process using the German MNCs' case. Hayden and Edwards (2001) examining the recent changes in HRM in Swedish MNCs, argue that the country of origin effect is eroding in the globalized economy.

The current state of empirical research, however, does not allow us to make a clear conclusion between two different arguments due to their methodological limits. In fact, previous studies have been criticized due to considerable methodological problems in ascertaining the country of origin effect in a definitive way (Ferner 1997; Geary/Roche 2002). We will examine them in depth later as the discussion unfolds, but their methodological problems can be summarized as being their descriptive nature or univariate analysis with no consideration for the control variables or other relevant explanatory variables. It is, therefore, necessary to reexamine the country of origin effect with more rigorous methods using a multivariate analysis.

Our study aims to examine the issue as to whether there exist significant differences in the HRM strategy between North American, European and Japanese subsidiaries. In doing so, our study has three distinctive methodological characteristics as compared to previous empirical studies. First of all, our study is based on a multivariate analysis, more exactly the multinominal logit regression to control the influences of other variables more so than country of origin. The control variables include industrial sector, firm size, labor union, and age. Second, it includes other variables that can explain the differences in the choice of the HRM strategy, such as entry strategy and investment strategy. Detailed explanations will be found in the related section. Lastly, we made a considerable effort to secure a sufficiently large enough sample allowing for a rigorous multivariate analysis. With this method and analysis, we expect to draw a more reliable conclusion concerning the country of origin effect.

We utilized a data set of 419 cases, collected from a survey of foreign subsidiaries in Korea with equal or more than $50 \%$ equity owned by MNCs. FDI in Korea has sharply increased after the financial crisis of 1997, due to the national effort to improve the investment environment with intensive restructuring of the Korean economy. The total amount of inward FDI, U.S.\$23.2 billion in 1966 quadrupled to U.S.\$ 93.3 billion in 1999. Traditionally, the principal investors in Korea are American and Japanese firms but European MNCs began to actively implant their subsidiaries in Korea, naming a few, such as Allianz Life, BASF, and Carrefour (Knight Ridder Tribune Business News 2003). The Korean setting, therefore, gives us a very serviceable field in that these three regions are well represented in terms of the number and size of FDI. In our sample, North American, Japanese and European subsidiaries represent $34.6 \%, 32.7 \%$, and $32.7 \%$ respectively. Korea is a country where the legal and institutional pressures are very strong in comparison to UK and Ireland, where most research over country of origin effect is done. Despite recent efforts of the Korean government to make the labor market flexible, the Korean labor laws, protective of the employees, regulate almost every aspect of HRM, and labor unions remain very active 
and combative. Given this fact, Korea as a research field, offers an interesting opportunity to examine if the country of origin effect observed in earlier studies exerts an important influence while under strong legal and institutional pressures.

\section{Theoretical background and hypotheses HRM Strategy of MNCs}

We examine the country of origin effect through the HRM strategies the MNCs adopt to manage their foreign establishments. Earlier research efforts examining country of origin effect compare principally various HRM practices in foreign establishments as shown in Table 1 . The assumption was that the MNCs would have different HRM practices according to the country of origin. However, specific HR practices are under the influence of local isomorphism, making it difficult to discern the real differences between countries of origin. Rosenweig and Nohria (1994) show that the HRM practices of foreign subsidiaries have a general tendency to follow local practices, with some differences among specific practices. In that case, the examination of HRM practices might hide the important differences in the strategic intention of MNCs of various countries of origin.

In addition, the same practice can be adopted for a different motive. For example, for some subsidiaries performance-based compensation might be introduced for the motive of transplanting the practice of the parent company, but for others, for motivating conformity to prevalent local practices. In this case, the examination of specific practice does not show significant difference between countries of origin despite the important difference in their strategic intention. This might hinder us from evaluating appropriately the country of origin effect. One promising alternative to better understand the effect of country of origin is to focus on the HRM strategy that MNCs choose to manage their foreign subsidiaries.

Table 1: HRM practices examined in previous research

\begin{tabular}{l|l}
\hline Authors & Compared practices \\
\hline Kopp(1994) & Staffing practices, International personnel policy \\
\hline $\begin{array}{l}\text { Rosenweig/ } \\
\text { Nohria(1994) }\end{array}$ & $\begin{array}{l}\text { Time off, Benefits, Gender composition, Training, Executive Bonus, } \\
\text { Participation }\end{array}$ \\
\hline $\begin{array}{l}\text { Inness/ } \\
\text { Morris(1995) }\end{array}$ & $\begin{array}{l}\text { Union recognition, Density and nature of bargaining, Working arrangements, } \\
\text { Employee communication and involvement, Single status conditions, Payment } \\
\text { and remuneration, Training }\end{array}$ \\
\hline $\begin{array}{l}\text { Roche/ } \\
\text { Geary (1996) }\end{array}$ & $\begin{array}{l}\text { Union recognition, Employer representation, Collective bargaining and in- } \\
\text { comes policy, Strike incidence, Third party involvement, Transnational collec- } \\
\text { tive bargaining }\end{array}$ \\
\hline $\begin{array}{l}\text { Guest/ } \\
\text { Hoque(1996) }\end{array}$ & $\begin{array}{l}\text { 27 HRM practices (job evaluation, profit sharing, sick pay, pensions, pay dis- } \\
\text { pute procedures, etc.) }\end{array}$ \\
\hline $\begin{array}{l}\text { Turner et al. } \\
(1997 a, 1997 b)\end{array}$ & $\begin{array}{l}\text { Union presence (union recognition, union density, works council presence), } \\
\text { Human resource flows (four practices including selection technique and per- } \\
\text { formance appraisal), Pay systems, Employee involvement }\end{array}$ \\
\hline $\begin{array}{l}\text { Geary/Roche } \\
(2001)\end{array}$ & $\begin{array}{l}\text { Reward practices, Pay determination, Voice practices, Flow practices, Work } \\
\text { organization, Union recognition and organization, Industrial relations practices, } \\
\text { Character of industrial relations, Management organization }\end{array}$ \\
\hline $\begin{array}{l}\text { Myloni et al. } \\
(2004)\end{array}$ & Selection, Compensation, Performance appraisal \\
\hline
\end{tabular}


For such reasons, Taylor et al. (1996) distinguished strategic international human resource management (SIHRM) from international HRM (IHRM). Similar to Taylor et al. (1996), we focus on strategic intention of MNCs, rather than particular HRM practices. MNCs have strategic choices in their HRM strategy for their foreign subsidiaries, along the dimension of the degree to which they try to conform to local practices or to transplant the practices of the parent company (Liu 2004).

In the literature, many authors have employed different expressions for this dimension of HRM strategies. In Heenan and Perlmutter's (1979) classification of IHRM strategy, a polycentric approach emphasizes the predominant role of the local environment conforming MNCs' HRM practices to it, while an ethnocentric approach underlines the role of headquarters imposing its HRM strategy and practices on foreign subsidiaries. Rosenweig and Nohria (1994) examine the HRM practices of foreign establishments in the perspective of the degree of their similarity to local practices. Coller and Marginson (1998) analyze the industrial relations of foreign affiliates along the dimension of global consistence and local adaptiveness.

All of this demonstrates that the HRM strategy of foreign establishments can be classified and examined between a localization strategy and a transplantation strategy. In a localization strategy, the parent company recognizes the cultural specificity of the local environment, and respects and adopts local HRM practices. In this strategy, the MNCs try to secure a familiar HRM environment for their local employees, and to avoid unnecessary conflicts with the local system. In a transplantation strategy, the parent company imposes patterns of HRM on its subsidiary. In doing so, the parent company tries to get a form of consistency in its worldwide HRM policy. In addition to the two typical strategies, Taylor et al. (1996) identified another middle-of-the road approach, namely integrative orientation. This is a kind of mixed strategy between localization and transplantation, in which MNCs try to adopt the best practices either from the parent company or from the local subsidiary. In this paper, we adopt three types of classification for the HRM strategies of MNCs for further analysis: localization strategy, transplantation strategy, and mixed strategy.

\section{Country of origin effect}

Generally speaking, the HRM practices and strategy are under the strong influence of the cultural and institutional factors due to their characteristics of "social embeddedness" (Nijs 1995). As pointed out by Ferner (1997), theoretically the country of origin effect can be explained by the different historical patterns and phasing of international expansion of home countries (Bartlett and Ghoshal, 1989), or different national business cultures (Hofstede, 1980). The MNCs' behaviors are, therefore, constrained consciously or unconsciously to their specific national culture or predetermined pattern. In this regard, the country of origin effect has a strong theoretical base, and many authors have tried to empirically test the country of origin effect.

Traditionally, the country of origin effect has been discussed using Japanese foreign establishments as the subject matter. With the spectacular economic performance of the Japanese economy during the 1980s, Japanese firms made a lot of FDI, and the transferability of the Japanese HRM system, considered often as the key factor of "Japanese success" received special attention (Ouchi 1981; Pascale/Athos 1981). This 
has led to many empirical bodies of research examining the transferability and impact of the Japanese management style on local HRM practices (Jain 1990; Wilkinson et al. 1993; Mason/Encarnation 1994; Wood 1996).

More serious empirical works aiming to examine the country of origin effect comparing the principal countries of origin have begun recently, in particular, dealing with the case of MNCs implanted in UK and Ireland where the MNCs' FDI has been very active (Hamil, 1984; Kopp 1994; Rosenweig/Nohria 1994; Innes/Morris 1995; Geary/Roche 2001).

For example, Hamil (1984), based on interviews with the managers in thirty MNCs in the UK, argues that American MNCs are more centralized in industrial relations decision making than European MNCs. Rosenweig and Nohria (1994), based on a sample of 249 American based foreign subsidiaries, find that there exist sharp differences in the HRM practices among affiliates of Canadian, Japanese and European MNCs, supporting strong country effects. Innes and Morris (1995) examine the country of origin effect using a total of forty-eight foreign subsidiaries, and show that U.S., Japanese and European MNCs in Wales are different in the use of HRM practices. According to their study, Japanese MNCs are more likely to have single union deals, a no-strike clause and collective bargaining. Japanese and U.S. MNCs are more likely to use job rotation, multi-skilling and autonomous work groups. German MNCs are least likely to use work councils. More recently, Geary and Roche (2001) using more than 400 samples, find that there exists still a strong country of origin effect, and that U.S. owned subsidiaries have distinctive characteristics compared to other European subsidiaries or Irish firms, in their HRM practices.

These results, except that of Geary and Roche (2001), however, have some methodological limitations in ascertaining the country of origin effect. The critical limitations are the small sample size, univariate analysis and absence of control variables, which are highly interrelated to each other. If the sample size is not sufficient, it is hardly possible to use a multivariate analysis. Moreover a univariate analysis does not need control variables. As we can see in Table 2, most empirical research uses simple descriptive statistics (Hamil, 1984; Kopp 1994; Innes/Morris 1994) or a univariate analysis such as t-test or Anova (Rosenweig/Nohria 1994; Turner et al. 1997a; Turner et al. 1997b). Because of these problems, the reliability of their results can be challenged: methodologically, the country of origin effect observed can come from the differences in the firm size, sector or other variables. For example, in attempting to refute the country of origin effect in non-union recognition practice, Roche and Turner (1994) argue that it can be better understood as a sector specific phenomenon of the electronics sector. Therefore, these variables have to be included in a statistical analysis as control variables. It is, therefore, necessary to reexamine the country of origin effect using more rigorous analysis techniques, specifically a multivariate analysis.

Arguing the necessity to implement controls for the other variables, Guest and Hoque (1996) use a logit regression to examine the country of origin effect between U.S., Japanese and German subsidiaries in the UK. Their findings, however, are based only on the 85 samples (25 U.S., 34 Japanese and 14 German subsidiaries) which do not constitute a sufficient sample size to secure statistical reliability. Geary and Roche (2001) criticize the methodological limitations of Turner et al.'s studies (1997a; 1997b) 
based on ANOVA and t-test, and strongly recommend the use of multivariate techniques allowing control for the other variables intervening in the country of origin effect, in particular, firm size and sector. They show, using more than 400 samples and the multiple logistic regression, that there exists still a strong country of origin effect, and that U.S. owned subsidiaries have distinctive characteristics compared to other European subsidiaries or Irish firms.

Table 2: Methods of previous empirical researches

\begin{tabular}{|c|c|c|c|c|c|}
\hline Authors & $\begin{array}{l}\text { Sample } \\
\text { size }\end{array}$ & $\begin{array}{l}\text { Host } \\
\text { country }\end{array}$ & $\begin{array}{c}\text { Home } \\
\text { countries }\end{array}$ & $\begin{array}{c}\text { Analysis } \\
\text { method }\end{array}$ & $\begin{array}{c}\text { Control } \\
\text { variables }\end{array}$ \\
\hline Hamil (1984) & 30 & UK & $\begin{array}{c}\text { North American } \\
\text { European. }\end{array}$ & $\begin{array}{l}\text { Descriptive } \\
\text { statistics }\end{array}$ & None \\
\hline Kopp(1994) & 81 & $\begin{array}{c}\text { Not } \\
\text { specified }\end{array}$ & $\begin{array}{c}\text { Not } \\
\text { specified }\end{array}$ & $\begin{array}{l}\text { Descriptive } \\
\text { statistics }\end{array}$ & None \\
\hline $\begin{array}{l}\text { Rosenweig/ } \\
\text { Nohria(1994) }\end{array}$ & 249 & USA & $\begin{array}{c}\text { Canada } \\
\text { European } \\
\text { Japanese }\end{array}$ & T-test & None \\
\hline $\begin{array}{l}\text { Inness } \\
\text { Morris(1995) }\end{array}$ & 48 & U.K. & $\begin{array}{c}\text { German } \\
\text { Japanese } \\
\text { North American }\end{array}$ & $\begin{array}{l}\text { Descriptive } \\
\text { statistics }\end{array}$ & None \\
\hline $\begin{array}{l}\text { Guest } \\
\text { Hoque (1996) }\end{array}$ & $145^{*}(85)$ & U.K. & $\begin{array}{c}\text { North American } \\
\text { European } \\
\text { Japanese }\end{array}$ & Logit analysis & $\begin{array}{l}\text { Size, union, } \\
\text { sector }\end{array}$ \\
\hline $\begin{array}{l}\text { Turner et al. } \\
(1997 a)\end{array}$ & $125^{\star}(60)$ & Ireland & $\begin{array}{c}\text { North American } \\
\text { European }\end{array}$ & T-test & None \\
\hline $\begin{array}{l}\text { Turner et al. } \\
\text { (1997b) }\end{array}$ & $101 *(73)$ & Ireland & $\begin{array}{c}\text { North American } \\
\text { European }\end{array}$ & ANOVA & None \\
\hline $\begin{array}{l}\text { Geary } \\
\text { Roche (2001) }\end{array}$ & 400 & Ireland & $\begin{array}{c}\text { North American } \\
\text { Other }\end{array}$ & $\begin{array}{l}\text { Logistic re- } \\
\text { gression }\end{array}$ & $\begin{array}{l}\text { Firm size, } \\
\text { sector }\end{array}$ \\
\hline $\begin{array}{l}\text { Myloni et al. } \\
(2004)\end{array}$ & $135(82)$ & Greece & $\begin{array}{c}\text { North American } \\
\text { European }\end{array}$ & T-test & None \\
\hline
\end{tabular}

* These samples include the indigenous firms and foreign subsidiaries at the same time.

The number in the parentheses is the sample size of foreign subsidiaries.

In spite of the methodological limitations discussed above, there is sufficient empirical evidence supporting the country of origin effect (Bartlett/Ghoshal, 1989; Bomers/Peterson 1977, Hamil 1984; Yeun/Hui 1993; Kopp 1994; Rosenweig/Nohria 1994; Innes/Morris 1995; Roche/Geary 1996). Therefore, the choice of the HRM strategy in foreign establishments would be different between countries of origin. The previous studies show that American MNCs have a more ethnocentric approach in their management (Bartlett/Ghoshal, 1989; Bomers/Peterson 1977; Hamil 1984; Yeun/Hui 1993), and, therefore, it is more likely to find transplantation strategy in American subsidiaries than in European or Japanese subsidiaries. On the contrary, Japanese MNCs have a tendency to adapt to the local environment and practices (Kobayashi, 1982; Negandhi et al. 1985; Rose/Kumar 2007). In particular this tendency may be more prevalent in Korea since Korea and Japan have been adopting similar HRM practices such as life-time employment and a seniority based HRM system. Hence, Japanese MNCs may not have to try to transfer their HRM practices into Korean sub- 
sidiaries. This leads us to think that the HRM strategy of Japanese foreign establishments would be positively related to a localization strategy. However, some studies (e.g., Kopp 1994) give contradictory findings concerning the HRM strategy of Japanese foreign establishments. This point needs to be verified through empirical testing. The research examining the country of origin effect of European MNCs is relatively small in amount (Ferner 1997), and it is therefore difficult to predict the direction of its influence on the choice of the HRM strategy by foreign establishments. ${ }^{1}$

H 1: The choice of the HRM strategy would be different according to the country of origin of the MNCs.

H 1a: The North American MNCs would be positively related to the transplantation strategy.

H 1b: The Japanese MNCs would be positively related to the localization strategy.

\section{Alternative strategic explanations}

It is important to note that the country of origin is not the only factor influencing the HRM strategy of foreign subsidiaries. The other factors that might influence the choice of strategy can be grouped into two categories: investment strategy and entry strategy.

\section{Investment strategy}

The context in which a FDI establishment was done needs to be considered in examining the country of origin effect. The HRM strategy of foreign subsidiaries can be influenced by investment strategy, which may be classified into two types: market orientation investment strategy and cost orientation investment strategy (Park and Yu 2000). In the case of investment for the cost advantage, the MNCs try to take advantage of the cost competitiveness of the local environment such as low labor cost, tax benefits, and/or low raw material costs. Then, it is more likely that the headquarters office tends to impose the HRM practices that have already been proved as efficient in their home country. On the contrary, when MNCs see Korean market in a long-term perspective as a hub of market expansion to other Asian markets, they have to carefully select key local talents, train and motivate them. Therefore, MNCs with a market orientation investment strategy are more likely adopt localization HRM strategy.

$\mathrm{H}$ 2: The choice of the HRM strategy would be different according to the investment strategy of the MNCs.

H 2a: The cost orientation investment strategy would be positively related to the localization strategy.

H 2b: The market orientation investment strategy would be positively related to the transplantation strategy.

1 We recognize that Europe is composed of culturally different countries and we should treat them separately. However, there are not sufficient samples to analyze each European country. We tried to analyze by region (e.g., North vs. South) but did not find any significant differences. So, we treat European countries as one category. 


\section{Entry strategy}

The HRM strategy of foreign subsidiaries can also be influenced by the entry strategy. In general, the FDI is done either through acquisition or through establishing a new entity ("greenfield site"). The greenfield site as an entry strategy tends to be chosen when MNCs want to replicate key features of the parent company (Bartlett and Ghoshal, 1989). Therefore, there are more chances that a transplantation strategy is adopted in greenfield site subsidiaries. On the other hand, the acquired establishments have a previous history and organizational inertia (Hanan/Freeman 1989), and they would be positively related to the localization strategy (Rosenweig/Nohria 1994).

$\mathrm{H}$ 3: The choice of the HRM strategy would be different according to the entry strategy of the MNCs.

H 2a: The M\&A strategy would be positively related to the localization strategy.

H 2b: The Greenfield site strategy would be positively related to the transplantation strategy.

\section{Control variables}

In addition, there are other factors related to the local context of each subsidiary, such as firm size, age, labor union, and industry. They can influence the HRM strategies and policies (Hanan and Freeman, 1989; Bartlett and Ghoshal, 1989; Rosenweign and Nohria 1994; Kochan and Cappelli, 1984; Roche and Turner 1994). These variables can explain the differences in the HRM strategy between various countries of origin. They will be, therefore, included in a statistical analysis as control variables.

\section{Method}

\section{Data and measurement}

The sample universe for this study consisted of about 5,000 foreign subsidiaries of MNCs in Korea, registered in the Ministry of Finance and Economy (MOFE) of Korea, in 1999. Every FDI in Korea must be registered to the MOFE, according to the Foreign Investment Law. Therefore, the database of MOFE has the most comprehensive directory concerning foreign subsidiaries in Korea. Since small firms are unlikely to have a systematic HRM policy, only companies with at least fifteen employees are included in the sample. Also, since FDI with at least $50 \%$ equity can influence management decision-making processes, only subsidiaries with at least 50\% equity are included in the sample. As a result, the final sample universe consisted of 650 subsidiaries. We mailed a questionnaire to the human resource director of each subsidiary after having contacted them by telephone to ask for their cooperation. We received completed responses from 479 of the subsidiaries, which represented a 74 percent response rate. This high response rate is due to the involvement of a professional research firm having a large network of HRM directors. After deleting missing cases and selecting only North American, European and Japanese cases, 419 foreign subsidiaries were used for the final analyses.

The dependent variable in this study is a HRM strategy that MNCs adopt to manage their workforce in Korea. In the survey questionnaire, we explained three generic strategies to the respondents, and asked them to choose one of them: localiza- 
tion, transplantation or mixed HRM strategy. Localization strategy is described as a general policy orientation that follows local HRM practices and systems prevalent in Korea. Transplantation strategy is described as a general policy orientation that transplants the HRM practices and systems of the parent company into Korean subsidiaries. Mixed strategy is described as one that mixes localization and transplantation in consideration of the situations. Among 419 foreign subsidiaries operating in Korea, 231 firms (55.1\%) choose a localization strategy whereas only 27 firms (6.4\%) choose a transplantation strategy. Another 161 firms (38.4\%) choose a mixed strategy.

For the validation check of HRM strategy measurement, we asked for two additional items of a 5-Likert scale related to HRM strategy in the survey: (1) We recognize and follow the local HRM practices in Korea as much as possible; (2) Our company has a worldwide policy of following local HRM practices because we believe that HRM is country specific. We ran ANOVA test to compare these two items with our measure of HRM strategy in order to check the validity of the measure. The results were consistent with the meaning of each strategy. The measures and definitions of other variables are reported in the Appendix.

Table 3: Validation check of HRM strategy measure

\begin{tabular}{l|c|c|c|c}
\hline & $\begin{array}{c}\text { Localization } \\
\text { strategy }\end{array}$ & Mixed strategy & $\begin{array}{c}\text { Transplantation } \\
\text { strategy }\end{array}$ & $\begin{array}{c}\mathrm{F} \text { value } \\
\text { (ANOVA) }\end{array}$ \\
\hline $\begin{array}{l}\text { Mean Score of } \\
\text { two items }\end{array}$ & 4.36 & 3.91 & 3.56 & $27.67^{* * *}$ \\
\hline $\mathrm{N}$ & 231 & 159 & 25 & \\
\hline${ }^{* * *} \mathrm{p}<0.01$ & \multicolumn{5}{l}{}
\end{tabular}

\section{Analyses and results}

Descriptive statistics and bivariate correlations of the variables are presented in Table 4. Correlation results show that manufacturing firms, larger firms, older firms, and unionized firms tend to implement a localization strategy. On the other hand, service firms, smaller firms, firms run by foreign management teams, younger firms, and nonunionized firms tend to implement a mixed HRM strategy. Transplantation strategy is negatively correlated with service industry and positively correlated with the cost orientation investment strategy. Table 4 also shows that, whereas Japanese MNCs tend to implement a localization strategy, North American MNCs tend to implement a mixed strategy. European MNCs do not show significant correlations with any generic strategies. These results are consistent with the result in the simple cross-table shown in Table 5. There is no difference among the three country groups in terms of choosing a transplantation strategy. On the other hand, among 145 North American subsidiaries, 73 firms (50.3\%) choose a mixed HRM strategy. Among 137 Japanese subsidiaries, 97 firms $(70.8 \%$ ) choose a localization strategy. Among 137 Europeans firms, 71 firms $(51.8 \%)$ choose a localization strategy.

The model of choosing an HRM strategy was estimated using multinominal logit regression models by predicting the log odds of choosing one of three HRM strategies. The estimates were based on the following equation:

$$
\log [\mathrm{p} /(1-\mathrm{p})]=\mathrm{x} \beta \text {, }
$$


where $\mathrm{p}$ is the probability of choosing the localization strategy (i.e., vs. transplantation strategy or mixed strategy) and $\mathrm{x}$ is a vector of independent variables. Maximum likelihood estimation was used for estimating parameters, $\beta$ using STATA 6.0.

Table 4: Mean, standard deviation and correlation of variables

\begin{tabular}{|c|c|c|c|c|c|c|c|c|c|c|c|c|c|c|c|c|c|c|c|c|c|c|}
\hline Variable & Mean & S.D & 1 & 2 & 3 & 4 & 5 & 6 & 7 & 8 & 9 & 10 & 11 & 12 & 13 & 14 & 15 & 16 & 17 & 18 & 19 & 20 \\
\hline 1. LOCAL & .55 & .50 & & & & & & & & & & & & & & & & & & & & \\
\hline 2. TRANS & .06 & .25 & -.29 & & & & & & & & & & & & & & & & & & & \\
\hline 3. MIXED & .38 & .49 & -.88 & -.21 & & & & & & & & & & & & & & & & & & \\
\hline 4. MANU1 & .09 & .28 & -.02 & .02 & .00 & & & & & & & & & & & & & & & & & \\
\hline 5. MANU2 & .40 & .49 & .07 & .02 & -.09 & -.25 & & & & & & & & & & & & & & & & \\
\hline 6. CHEMICAL & .24 & .43 & .04 & .06 & -.07 & -.17 & -.46 & & & & & & & & & & & & & & & \\
\hline 7. SERVICE & .27 & .44 & -.12 & -.09 & .17 & -.19 & -.49 & -.34 & & & & & & & & & & & & & & \\
\hline 8. SIZE 1 & .33 & .47 & -.19 & .00 & .19 & -.05 & -.05 & -.05 & .14 & & & & & & & & & & & & & \\
\hline 9. SIZE 2 & .25 & .43 & .06 & .01 & -.06 & .08 & -.05 & .01 & $.00-$ & -.41 & & & & & & & & & & & & \\
\hline 1. SIZE 3 & .28 & .45 & .05 & .03 & -.07 & .00 & .06 & .11 & -.17 & -.44 & -.36 & & & & & & & & & & & \\
\hline 11. SIZE 4 & .14 & .35 & .12 & -.05 & -.09 & -.03 & .05 & -.07 & $.04-$ & -.28 & -.23 - & -.25 & & & & & & & & & & \\
\hline $\begin{array}{l}\text { 12. FOREIGN } \\
\text { MGMT }\end{array}$ & .74 & .44 & -.23 & .05 & .22 & .03 & -.08 & -.04 & .12 & .16 & .01 & -.09 & -.12 & & & & & & & & & \\
\hline 13. ORG AGE & 10.74 & 8.26 & .17 & -.03 & -.16 & -.07 & .05 & .21 & $-.21-$ & -.36 & -.06 & .17 & .35 & -.11 & & & & & & & & \\
\hline 14. UNION & .29 & .45 & .17 & -.04 & -.15 & -.01 & .05 & .07 & $-.12-$ & $-.41-$ & -.17 & .28 & .41 & -.07 & .42 & & & & & & & \\
\hline 15. COST & 8.16 & 2.42 & .11 & .10 & -.16 & -.06 & .26 & -.06 & -.25 & -.23 & .06 & .13 & .07 & -.25 & .26 & .16 & & & & & & \\
\hline 16. MARKET & 11.00 & 1.95 & -.07 & .01 & .06 & .03 & -.09 & .06 & $.02-$ & -.02 & -.02 - & \begin{tabular}{|l|l}
-.02 & \\
\end{tabular} & .06 & .10 & -.15 & $-.04-$ & -.14 & & & & & \\
\hline 17. M\&A & .07 & .26 & -.00 & .00 & .00 & .11 & \begin{tabular}{|l|l|}
-.08 \\
\end{tabular} & .06 & $.02-$ & -.04 & .07 & \begin{tabular}{|l|l|}
-.03 & \\
\end{tabular} & .02 & .09 & $-.2-$ & $-.02-$ & -.09 & .00 & & & & \\
\hline $\begin{array}{l}\text { 18. GREEN- } \\
\text { FIELD }\end{array}$ & .77 & .42 & .01 & .00 & .01 & .00 & $.06-$ & -.05 & \begin{tabular}{|l|l}
.02 \\
\end{tabular} & .03 & -.04 & .01 & .01 & .03 & .14 & .03 & $.04-$ & -.06 & -.52 & & & \\
\hline 19. JAPAN & .33 & .47 & .22 & .00 & -.23 & -.05 & $.19-$ & -.03 & $-.15-$ & -.09 & .02 & $.11-$ & -.05 & -.28 & .22 & .17 & $.34-$ & $-.26-$ & -.18 & .07 & & \\
\hline $\begin{array}{l}\text { 20. N. AMERI- } \\
\text { CA }\end{array}$ & .35 & .48 & -.17 & -.01 & .18 & .03 & -.12 & -.04 & .16 & -.01 & -.05 & -.04 & .12 & .10 & -.06 & -.08 & -.2 & .1 & .12 & -.09 & -.51 & \\
\hline 21. EUROPE & .33 & .47 & -.05 & .00 & .05 & .02 & -.06 & .07 & \begin{tabular}{|l|l}
-.02 \\
\end{tabular} & .10 & $.03-$ & $-.07-$ & -.08 & $.17-$ & \begin{tabular}{|l|l}
-.16 & - \\
\end{tabular} & $-.08-$ & -.14. & .16 & .06 & .01 & -.49 & -.51 \\
\hline $\mathrm{N}$ & 419 & & & & & & & & & & & & & & & & & & & & & \\
\hline
\end{tabular}

All correlation larger than .10 is statistically significant at .05 level; larger than .13 significant at .01 level.

Table 5: Cross-table between HRM strategy and country of origin

\begin{tabular}{l|c|c|c}
\hline & Localization & Transplantation & Mixed \\
\hline North America & $63(43.3 \%)$ & $9(6.2 \%)$ & $73(50.3 \%)$ \\
\hline Japan & $97(70.8 \%)$ & $9(6.6 \%)$ & $31(22.6 \%)$ \\
\hline Europe & $71(51.8 \%)$ & $9(6.7 \%)$ & $57(41.6 \%)$ \\
\hline $\mathrm{N}$ & $231(55.1 \%)$ & $27(6.4 \%)$ & $161(38.4 \%)$ \\
\hline
\end{tabular}

Table 6 reports the results of estimates of the multinominal logit models for HRM strategy of MNCs. As shown in Table 6, we analyzed the impact of each variable in- 
cluding countries of origin according to three possible choices of HRM strategy: transplantation vs. localization, transplantation vs. mixed, and localization vs. mixed. The results show that the extent to which independent variables influence a firm's choice of an HRM strategy sharply differ in three columns, representing different choices of HRM strategies. The first column shows the influences of independent variables on the choice of a transplantation strategy against a localization strategy. Here, the country of origin does not influence the choice of a transplantation strategy. Rather, industry, cost motive of investment and foreign management significantly influence this choice statistically. The subsidiaries in the chemical industry, subsidiaries with cost-oriented investment strategy and subsidiaries managed by foreign management tend to choose a transplantation strategy instead of a localization strategy.

Table 6: Multinominal logit estimates of HRM strategy of MNCs

(standard errors in parentheses)

\begin{tabular}{|c|c|c|c|}
\hline Variables & $\operatorname{Pr}$ (Trans/Local) & $\operatorname{Pr}($ Trans/Mixed) & $\operatorname{Pr}$ (Local/Mixed) \\
\hline Manufacturing 1 (vs. Service) & $\begin{array}{l}1.527 \\
(.972) \\
\end{array}$ & $\begin{array}{l}1.750^{*} \\
(.978)\end{array}$ & $\begin{array}{c}.223 \\
(.428) \\
\end{array}$ \\
\hline Manufacturing 2 (vs. Service) & $\begin{array}{l}1.109 \\
(.812)\end{array}$ & $\begin{array}{l}1.454^{*} \\
(.812)\end{array}$ & $\begin{array}{c}.344 \\
(.285) \\
\end{array}$ \\
\hline Chemical (vs. Service) & $\begin{array}{l}1.435^{*} \\
(.845)\end{array}$ & $\begin{array}{l}1.891^{* *} \\
(.850)\end{array}$ & $\begin{array}{l}.455 \\
(.329) \\
\end{array}$ \\
\hline COST & $\begin{array}{l}.224^{* *} \\
(.104)\end{array}$ & $\begin{array}{l}.187^{*} \\
(.106)\end{array}$ & $\begin{array}{l}-.037 \\
(.053) \\
\end{array}$ \\
\hline MARKET & $\begin{array}{l}.005 \\
(.117)\end{array}$ & $\begin{array}{c}.011 \\
(.121)\end{array}$ & $\begin{array}{l}.006 \\
(.061)\end{array}$ \\
\hline Size 1 & $\begin{array}{c}.347 \\
(.138) \\
\end{array}$ & $\begin{array}{l}-.260 \\
(.581) \\
\end{array}$ & $\begin{array}{l}-.608^{\star *} \\
(.300) \\
\end{array}$ \\
\hline Size 3 & $\begin{array}{l}.138 \\
(.612) \\
\end{array}$ & $\begin{array}{l}.082 \\
(.633)\end{array}$ & $\begin{array}{l}-.220 \\
(.328) \\
\end{array}$ \\
\hline Size 4 & $\begin{array}{l}-.012 \\
(.980) \\
\end{array}$ & $\begin{array}{c}.102 \\
(.1 .011) \\
\end{array}$ & $\begin{array}{c}.114 \\
(.446) \\
\end{array}$ \\
\hline FOREIGN MGMT & $\begin{array}{l}1.016^{*} \\
(.560)\end{array}$ & $\begin{array}{c}.110 \\
(.589)\end{array}$ & $\begin{array}{c}-.906^{\star * *} \\
(.289) \\
\end{array}$ \\
\hline ORG AGE & $\begin{array}{l}.040 \\
(.036)\end{array}$ & $\begin{array}{l}.019 \\
(.037)\end{array}$ & $\begin{array}{c}.022 \\
(.018)\end{array}$ \\
\hline UNION & $\begin{array}{c}-.618 \\
(.639) \\
\end{array}$ & $\begin{array}{l}-.379 \\
(.663) \\
\end{array}$ & $\begin{array}{c}.239 \\
(.319) \\
\end{array}$ \\
\hline M\&A (vs. Greenfield) & $\begin{array}{c}-.992 \\
(1.122)\end{array}$ & $\begin{array}{c}-.534 \\
(1.137)\end{array}$ & $\begin{array}{c}.457 \\
(.436)\end{array}$ \\
\hline JAPAN (vs. EUROPE) & $\begin{array}{l}-.106 \\
(.583)\end{array}$ & $\begin{array}{c}.478 \\
(.604)\end{array}$ & $\begin{array}{l}.585^{\star} \\
(.308)\end{array}$ \\
\hline N. AMERICA (vs. EUROPE) & $\begin{array}{c}.367 \\
(.560)\end{array}$ & $\begin{array}{l}-.096 \\
(.560)\end{array}$ & $\begin{array}{l}-.463^{*} \\
(.266)\end{array}$ \\
\hline JAPAN (vs. N. AMERICA) ${ }^{1)}$ & $\begin{array}{l}-.473 \\
(.578)\end{array}$ & $\begin{array}{c}.574 \\
(.592)\end{array}$ & $\begin{array}{c}1.047^{* * *} \\
(.312)\end{array}$ \\
\hline Constant & $\begin{array}{c}-5.487^{* * *} \\
(1.924) \\
\end{array}$ & $\begin{array}{l}-4.409 \\
(1.977) \\
\end{array}$ & $\begin{array}{l}1.078 \\
(.937) \\
\end{array}$ \\
\hline
\end{tabular}

Log Likelihood $=-321.80 ;$ Chi-square $=71.510^{\star * *} ;$ Pseudo R-square $=.100$

${ }^{*} p<.10 ;{ }^{* *} p<.05 ;{ }^{* * *} p<.01$ (two-tailed tests)

1) We ran the same multinomial regression twice using different base category in order to show every possible combination of comparison between countries of origin. 
As Hamil (1984) points out, the subsidiaries operating under a global chain tend to have more centralized decision-making. The chemical industry is characterized by a strong rationalization of production under a global point of view: the production is assured by a small number of facilities having a large capacity of production, and the distribution channel is organized globally or regionally. Moreover, this integration in the global production and distribution chain seems to explain why the chemical MNCs choose a transplantation strategy. The cost orientation strategy of FDI is found to cause MNCs to choose a transplantation strategy as we expected. This finding sheds some light on the reason why cost orientation strategy is reported negatively related to the industrial relations climate in foreign subsidiaries. Park and Yu (2000) report that cost motive is negatively related with labor-management relations. The cost orientation strategy makes the MNCs choose the transplantation strategy, and the chances are that this strategy negatively influences the industrial relations climate in foreign subsidiaries. The preference of a foreign management team for transplantation can be explained by the fact that they prefer the HRM system to which they are familiar.

The factors determining the choice between a transplantation and mixed strategy are presented in the second column in Table 6. The results are very similar to those of the choice between transplantation and localization except for the significance levels. In particular, the variable for foreign management is not significant, whereas all three variables for the industry type are statistically significant.

The last column of Table 6 reports estimates of choosing a localization strategy against a mixed strategy. The column clearly shows that the countries of origin play an important role in choosing a localization strategy over a mixed strategy. All coefficients of the three countries of origin are statistically significant. The coefficient for Japanese MNCs is 0.585 when they are compared with European MNCs, and 1.047 when compared to North American MNCs. The coefficient for North American MNCs is -0.463 when they are compared with European MNCs. These results disclose that the estimated log odds of choosing a localization strategy over a mixed strategy by Japanese subsidiaries are 1.79 times higher than European subsidiaries and 2.85 times higher than North American subsidiaries; those by European subsidiaries are 1.59 times higher than North American subsidiaries. These findings are consistent with the results of previous studies in the literature.

\section{Discussion}

The empirical results partially support the country of origin effect, in that it exists when the MNCs are faced with the choice between localization and mixed strategy. The results confirm the previous studies asserting that Japanese MNCs prefer a localization strategy (Negandhi et al. 1985; Kobayashi 1982). However, we found also that the country of origin does not play a significant role in the choice between transplantation and other strategies. In this case, while situational factors such as industry or investment strategy are shown to play a predominant role, the country of origin shows no explanatory power on firms' choices for HRM strategy.

The findings we obtained from empirical analyses raise some interesting issues to be discussed. It may be natural to pose a question why the country of origin effect is absent in the choice of transplantation. In fact, the transplantation strategy is an ex- 
ceptional choice MNCs may take, for it represents only $6 \%$ of the responses. Two explanations may be possible. First is the simple observation that it is not very effective for MNCs to transplant their HRM strategy to local subsidiaries since many countries such as Korea have been developing their own HRM systems with economic growth. An alternative explanation would be that the choice of transplantation is determined by rational considerations, not by the MNCs' cultural predisposition, represented by countries of origin. For example, when the FDI is done in pursuit of cost orientation strategy, there are tendencies irrespective of countries of origin to choose transplantation. In other words, when there are some environmental factors making this strategy necessary for the management of subsidiaries, they choose the transplantation strategy. That explains why the differences between countries of origin do not play a significant role in the choice of transplantation. On the other hand, concerning the choice between localization and mixed strategy, MNCs are not faced with urgent environmental pressure, and this may explain why their choice is largely determined by country of origin.

In contrast to our expectations, we could not find any significant results regarding the effects of MNCs' entry strategy on HRM strategy. M\&A style of entry strategy was minor when this survey was conducted. Only about $7 \%$ of MNCs in this sample used M\&A when they established subsidiaries. Maybe the sample size for M\&A cases is too small for the statistical significant. Otherwise there is no difference in HRM strategies regarding entry strategy. We need further research on this issue in the future.

We found significant differences in choosing an HRM strategy between North American, European and Japanese subsidiaries. While controlling other variables assumed to influence the choice of HRM strategies, Japanese MNCs are shown to prefer a localization strategy more so than North American or European MNCs. European MNCs show more localization orientation in their choice than North American MNCs. Our empirical results support the differences resulting from countries of origin that many authors asserted in the literature (Kopp 1994; Rosenweig/Nohria 1994; Innes/Morris 1995; Roche/Geary 1996; Geary/Roche 2001). An explanation can be drawn from the difference in cultural values of the countries of origin. The relevant value in this regard is "universalism-particularism". According to Trompenaars and Hampden-Turner (1997), universalism is a tendency to apply rules and procedures universally to ensure equity and consistency, while particularism is a tendency to encourage flexibility by adapting to particular situations. Their results based on the survey from MNCs' managers of different countries show consistently that, among the three regions, North Americans are the most universalist, while Japanese are the most particularist. Europeans are between them. With this value difference in mind, it is not difficult to expect Japanese MNCs to choose a localization HRM strategy more than North American or European MNCs, which is supported by our empirical findings.

In this study, we examined only European, Japanese, and North American MNCs. We have seen many other Asian firms, in particular Korean firms such as Samsung, LG, SK, POSCO, Hyundai, and etc., entering the global market. Now, IHRM research should turn their focus on these new worlds.

By defining a generic HRM strategy and using multivariate statistical analysis, we found interesting results regarding controversial issues in international management of 
MNCs. However, our study has some limitations that have to be overcome in future studies. First of all, our concern was limited to the generic HRM strategy, a general intent of HRM policy of MNCs. As mentioned earlier in the paper, our choice of the generic strategy as a dependent variable was based on the fact that it is a more appropriate tool than specific HRM practices to analyze the country of origin effect. This intended strategy, however, may be somewhat different from actual HRM policies that MNCs implement for their subsidiaries. Also different level of policies and practices may yield different strategic choices. For instance, strategic HRM decisions such as human resource planning and recruiting of executives may be made based on a transplantation strategy whereas a localization strategy may be chosen for guiding HRM decisions such as pay increase and recruiting of low level managers. In this regard, the country of origin may play the most important role at the strategic intention level, while the other context variables may play important roles at the operational level concerning the introduction of specific practices. Our research does not allow us to answer to this speculation, and further research is needed.

Another limitation concerns the situational factors forcing the MNCs to choose a transplantation strategy. In general, it is known that the transplantation strategy causes many negative effects on the industrial relations of foreign subsidiaries (Enderwick, 1985; Veersma 1995, Park and Yu 2000). In spite of these negative side effects, there are MNCs choosing a transplantation strategy. Our study found some factors determining this choice. However, there can be other factors leading MNCs to choose a transplantation strategy.

The method of measuring HRM strategy as a single questionnaire item also would be a limitation in understanding the transplantation strategy of MNCs. Our study does not fully investigate them. It would be very interesting to clarify them for the policy implications of the management of MNCs.

In addition, our study does not allow us to compare the differences in the choice of HRM strategies between European countries. Europe is composed of countries with different cultures, and the grouping of them in one category weakens the validity of findings. However, the number of European cases is not sufficient to analyze each European country.

\section{Conclusion}

In conclusion, we live in the globalization era. IHRM of MNCs has been an increasingly important research field elsewhere in the world. We believe that our study made a contribution in understanding the country of origin effect of MNCs' HR strategy of one host country setting, Korea, where the speed of globalization has been unprecedented. However, our understanding of IHRM strategies of MNCs is still very limited.

At least two research arrears are urgent in a near future. First one would be performance implication of different HR strategies of MNCs. The level of analysis was national one in this research as well as many other IHRM research. It is difficult to identify performance effect at the national level research. Now we have to turn our interest into firm level of IHRM and its performance implication.

Second, as seen in our study, pure transplantation HR strategy is rare now. Most MNCs tend to choose either localization or mixed HR strategy. It means that MNCs 
use different HR strategy, therefore different HR practices and polices to different countries. However, we have little knowledge on what kind of HR strategy MNCs use in different country settings. In particular we need further research on how emerging countries' MNCs such as Korea, China, Taiwan, India, and Malaysia, implement HR strategy on different host countries including Europe and N. America.

\section{References}

Bartlett, C. A./Ghoshal, S. (1989): Managing across borders: the transnational solution. Boston. Harvard Business School Press.

Bomers, G./Peterson, R. (1977): Multinational corporations and industrial relations: the case of West Germany and the Netherlands. In: British Journal of Industrial Relations, 15(1): 45-62.

Coller, X./Marginson, P. (1998): Transnational management influence over changing employment practice: a case from the food industry. In: Industrial Relations Journal, 29(1): 4-17.

Edwards, T. (1998): Multinationals, Employment Practices and the Process of Diffusion. In: International Journal of Human Resource Management, 9(4): 696-709.

Enderwick, P. (1985): Multinational Business and Labor. Croom Helm, London and Sydney.

Ferner, A. (1997): Country of origin effects and HRM in Multinational companies. In: Human Resource Management Journal, 7(1): 19-37.

Ferner, A./Varul, M. (2000): Vanguard Subsidiaries and the Diffusion of New Practices: A Case Study of German Multinationals. In: British Journal of Industrial Relations, 38(1): 115-140.

Geary J. F./Roche, W. K. (2001): Multinationals and Human Resource Practices in Ireland: A Rejection of the New Conformance Thesis. In: International Journal of Human Resource Management, 12(1): 1-19.

Glover, L./Wilkinson, A. (2007): Worlds colliding: the translation of modern management practices within a UK based subsidiary of a Korean-owned MNC. In: The International Journal of Human Resource Management, 18(8): 1437-1455.

Guest, D./Hoque, K. (1996): National ownership on HR practices in UK greenfield sites. In: Human Resource Management Journal, 6(4): 50-74.

Hamil, J. (1984): Labor Relations Decision Making Within Multinational Corporations. In: Industrial Relations Journal, 15(2): 30-34.

Hanan, M. T./Freeman, J. (1989): Organizational ecology. Cambridge: Harvard Business Press.

Hayden, A./Edwards, T. (2001): The Erosion of the Country of Origin Effect: A Case Study of a Swedish Multinational Company. In: Relational Industrielles-Industrial Relations, 56(1): 116-140.

Heenan, D. A./Perlmutter, H. V. (1979): Multinational Organization Development. Reading: MA: Addison-Wiley.

Hofstede, G. (1980): Culture's Consequences. London: Sage.

Holtbruegge, D./Berg, N. (2004): How multinational corporations deal with their socio-political stakeholders: an empirical study in Asia, Europe, and the US. In: Asian Business and Management, 3: 299-313.

Innes, E./Morris, J. (1995): Multinational corporations and employee relations: Continuity and change in a mature industrial region. In: Employee Relations, 17(6): 25-42.

Jain, H. C. (1990): Human resource management in selected Japanese firms, their foreign subsidiaries and locally owned counterparts. In: International Labor Review, 129(1): 73-84.

Knight Ridder Tribune Business News. (2003): Economic growth in the West may rest on selling goods to Asian shoppers, Jan. 5: 1.

Kobayashi, N. (1982): The present and future of Japanese multinational enterprises. In: International Studies of Man and Organization, 12(1): 38-58.

Kochan, T. A./Cappelli, P. (1984): The Transformation of the Industrial Relations and Personnel Function. In: Ostermann, P. (Ed.): Internal Labor Market. Cambridge, MA: MIT Press.

Kopp, R. (1994): International Human Resource Policies and Practices in Japanese, European and United States Multinationals. In: Human Resource Management, 33(4): 581-599. 
Liu, W. (2004): The cross-national transfer of HRM practices in MNCs: an integrative research model. In: International Journal of Manpower, 25(6): 500-517.

Mason, M./Encarnation, D. (Eds.) (1994): Does Ownership Matter? Japanese Multinationals in Europe. Oxford: Clarendon Press.

Myloni, B./Harzing, A. K./Mirza, H. (2004): Host country specific factors and the transfer of human resource management practices in multinational companies. In: International Journal of Manpower, 25(6): 518-534.

Negandhi, A. R./Eshgi, G. S./Yuen, E. C. (1985): The management practices of Japanese subsidiaries overseas. In: California Management Review, 27(4): 93-105.

Nijs W. de (1995): International human resource management and industrial relations: a framework for analysis. In: International Human Resource Management: An Integrated Approach. (Eds. Harzing A. W./Ruysseveldt J. V.), London: SAGE Publications.

Ouchi, W. G. (1981): Theory Z. Addison-Wesley Publishing Co.

Park, W./Yu, G. (2000): Determinants of Management Labor Relations of Foreign Subsidiaries in Korea. In: Proceeding of IIRA 12th World Congress, Tokyo, May-June.

Pascale, R. T./Athos, A. G. (1981): The Art of Japanese Management. New York, Simon and Schuster.

Roche, W. K./Geary, J. (1996): Multinational companies in Ireland: Adapting or diverging from national industrial relations practices and traditions? In: Irish Business and Administrative Research, 17: 1431.

Roche, W. K./Turner, T. (1994): Testing Alternative Models of Human Resource Policy Effects on Trade Union Recognition in the Republic of Ireland. In: International Journal of Human Resource Management, 5: 721-53.

Rose, R. C./Kumar, N. (2007): The transfer of Japanese-style HRM to subsidiaries abroad. In: Cross Cultural Management, 14(3): 240-253.

Rosenweig P. M./Nohria, N. (1994): Influences on human resource management practices in multinational corporations. In: Journal of International Business Studies, 25(2): 229-251.

Trompenaars, F./Hampden-Turner (1997): Riding the Waves of Culture. McGraw-Hill.

Turner, T./D’Art, D./Gunnigle, P. (1997a): U.S. Multinationals: changing the framework of Irish Industrial relations? In: Industrial Relations Journal, 28(2): 92-102.

Turner, T./D’Art, D./Gunnigle, P. (1997b): Pluralism in Retreat? A Comparison of Irish and Multinational Manufacturing Companies. In: International Journal of Human Resource Management, 8(6): 825-840

United Nations (2000): World Investment Report. New York: United Nations.

Veersma U. (1995): Multinational Corporations and industrial relations: policy and practice. In: International Human Resource Management: An Integrated Approach. (Eds. Harzing A. W./Ruysseveldt J. V.) London: SAGE Publications.

Wilkinson, B./Morris, J./Munday, M. (1993): Japan in Wales: a new IR. In: Industrial Relations Journal, 24(4): 273-283.

Wood, S. (1996): How Different Are Human Resource Practices in Japanese 'Transplants' in the United Kingdom. In: Industrial Relations, 35(4): 511-525.

Yeun, E./Hui, T. K. (1993): Headquarters, host culture and organizational influences on HRM policies and practices. In: Management International Review, 33(4): 361-383. 


\section{Appendix}

\section{Measurement and variable definition}

\begin{tabular}{|c|c|}
\hline Variables & Definition \\
\hline Local & 1 if the subsidiary chooses local HRM strategy; 0 otherwise \\
\hline Mixed & 1 if the subsidiary chooses mixed HRM strategy; 0 otherwise \\
\hline Trans & 0 if the subsidiary chooses transplantation HRM strategy; 0 otherwise \\
\hline Manufacture 1 & $\begin{array}{l}1 \text { if the firm belongs to food, tobacco, textile, paper industry; } 0 \text { other- } \\
\text { wise }\end{array}$ \\
\hline Manufacture 2 & 1 if the firm belongs to mining, machine, metal industry; 0 otherwise \\
\hline Chemical & 1 if the firm belongs to chemical, plastic, lubber industry; 0 otherwise \\
\hline SERVICE & 1 if the firm belongs to service industry; 0 otherwise. \\
\hline SIZE 1 & 1 if the firm has less than 50 total employees; 0 otherwise. \\
\hline SIZE 2 & 1 if the firm has $50-100$ total employees; 0 otherwise. \\
\hline SIZE 3 & 1 if the firm has $101-300$ total employees; 0 otherwise. \\
\hline SIZE 4 & 1 if the firm has more than 300 total employees; 0 otherwise. \\
\hline \multirow[t]{2}{*}{ FOREIGN MGMT } & 1 if the firm is managed by foreign management team; \\
\hline & 0 if the firms is managed by Korean management team. \\
\hline ORG AGE & 1999 - established year. \\
\hline UNION & 1 if employees of the firm are unionized; 0 otherwise. \\
\hline COST & $\begin{array}{l}\text { factor score from three variables indicating cost orientation investment } \\
\text { strategy: (1) utilization of low labor-cost, (2) utilization of tax benefits, } \\
\text { and (3) utilization of low raw material cost. }\end{array}$ \\
\hline MARKET & $\begin{array}{l}\text { factor score from three variables indicating market orientation invest- } \\
\text { ment strategy: (1) the attractiveness of Korean market, (2) utilization as } \\
\text { a base camp for the expanding Asian market, and (3) long-term in- } \\
\text { vestment for Korean market expansion. }\end{array}$ \\
\hline$M \& A$ & $\begin{array}{l}1 \text { if the multinational establishes subsidiary through merge and acquisi- } \\
\text { tion; } 0 \text { otherwise. }\end{array}$ \\
\hline GREENFIED & $\begin{array}{l}1 \text { if the multinational establishes completely new subsidiary; } 0 \text { other- } \\
\text { wise. }\end{array}$ \\
\hline JAPAN & 1 if the country of origin is Japan; 0 otherwise. \\
\hline N. AMERICA & 1 if the country of origin is either USA or Canada; 0 otherwise. \\
\hline EUROPE & 1 if the country of origin is Europe; 0 otherwise. \\
\hline
\end{tabular}

